\title{
Beskyttelse som ledd i behandlingen av selvmordsnære pasienter i psykiatriske døgnavdelinger
}

\author{
Ved Gry Bruland Vråle
}

\begin{abstract}
Observasjon og ivaretakelse av selvmordsnære pasienter i akuttpsykiatrisk avdeling er en utfordrende behandlingsoppgave som kan beskrives som et dynamisk forhold mellom å beskytte pasienter mot selvskade og det å etablere en behandlingsallianse. Noen tidligere studier samt veiledningssamtaler jeg har hatt med sykepleiere som har beskrevet sin praksis på dette feltet, har gitt inspirasjon til denne artikkelen som fokuserer på det strukturelle og det substansielle innholdet i behandlingstiltaket "beskyttelse mot selvmord og selvskade" innen rammen av en psykiatrisk døgnenhet.
\end{abstract}

\section{Innledning}

I Norge har man i dag ikke ensartede begreper som beskriver behandling av pasienter som er alvorlig selvmordstruet (Vråle et al., 2000). Ordet fotfølging brukes av mange for å beskrive den mest beskyttende omsorgen. Det kan fungere som en metafor som beskriver både overvåkingen av og nærheten til pasienten. Andre omtaler dette omsorgsnivået som fase 1 eller fast vakt, på engelsk: special observation, maximum observation og constant observation (Bowers, Gournay \& Duffy, 2000). Innholdet i fotfølging kan beskrives nærmere på følgende måte: "Ved fotfølging ses pasienten til enhver tid og man må ikke snu ryggen til ham. En må være så fysisk nær at enhver farlig situasjon må kunne avverges, pasienten må følges på WC, og en må være til stede i samme rom ved dusjing. På natt sitter sykepleieren i døråpningen, leser ikke og nattlys skal være på. En observerer respirasjon i forhold til søvn og våkenhet og må ha oversikt over hva pasienten foretar seg i sengen.” (Vråle \& Mjøsund, 2005) På neste omsorgsnivå beholder personalet fortsatt ansvaret for å beskytte pasienten mot å ta sitt eget liv, men etter nærmere risikovurdering finner man nå at pasienten kan være på egenhånd i 5-15 minutter av gangen. Om dette beskyttelsestiltaket brukes betegnelser som vite hvor er, hyppig tilsyn eller fase 2. Vite hvor er kan handle om at man til enhver tid vet hvor pasienten befinner seg i avdelingen, og hvor pasienten befinner seg psykologisk og eksistensielt i forhold til selvmord. Både fotfølging og vite hvor er anvendes i psykiatriske døgnenheter til beskyttelse for så vel frivillig innlagte som for tvangsinnlagte selvmordsnære pasienter. Når pasienten senere kan overta mer ansvar for å ikke skade seg, kan man i en overgangsfase bruke avtaler som et beskyttelsestiltak for å forebygge selvmord (Vatne, 2001).

Den nærheten som oppstår mellom pasient og behandlere ved fotfølging av pasienten i avdeling, kan utnyttes terapeutisk gjennom samtaler om betydningsfulle tema for pasienten. Det kan gi dypere innsikt og kanskje åpne for nye muligheter i livet. Det kan f.eks. være å bli oppmerksom på hvordan opplevelse av meningsløshet kan føre til akutte selvmordskriser. Samtaler om dette kan gi pasienten bedre forståelse for hva han kan gjøre i stedet for å skade seg, f.eks. at han finner en strategi for å søke hjelp. Bevissthet om viktige verdier som gjelder pasientens integritet, hans rett til å gjøre egne valg, men også om helsepersonellets plikt til å beskytte livet, er viktige aspekter ved den kompetanse som må kreves av dem som arbeider med selvmordsnære pasienter. Kunnskap og ferdigheter i beskyttelsestiltak og relasjonsbygging er også viktig. De psykoterapeutiske aspektene ved pasientovervåking er beskrevet av Dodds \& Bowels (2001). De understreker betydningen av å utvikle evne til å vise engasjement og vilje til å skape håp for pasienten som viktige kompetanseområder for dem som deltar i behandlingen av selvmordsnære. Vråle \& Steen (2005) beskriver organisatoriske faser og det dynamiske forholdet mellom kontroll og behandling i fotfølging. Med utgangspunkt i denne studien skal vi i denne artikkelen gi en nærmere beskrivelse av ulike beskyttelsestiltak overfor selvmordsnære pasienter i akuttpsykiatrisk avdeling.

\section{Fotfølging}

Fotfølging må ses i sammenheng med organisatoriske strukturer og prosedyrer og som en begynnende terapeutisk relasjon.

\section{Hovedfase 1}

Vurdering av selvmordsrisiko inngår i enhver psykiatrisk vurdering. Ut fra observasjoner og intervju med pasienter vurderes eksempelvis grad av håpløshet og opplevelse av meningsløshet, livssituasjon
Hovedfase 1

- Vurdering av selvmordsrisiko

- Vurdering av behov for beskyttelse

- Beslutning og iverksetting av fotfølging - skjer i rask rekkefølge

\section{Introduksjon}

- Iverksetting og etablering av fotfølging

- Informasjon

- Dokumentasjon

Hovedfase 2

- Etablering og gjennomføring av fotf $\varnothing$ lging

- Beskyttelse

- Nærvær og samtale

- Selvmordsfare og behov for beskyttelse vurderes fortløpende

\section{Avslutning}

- Intensivering av vurdering av selvmordsrisiko, av allianse, pasientens egen beskyttelse og behov for beskyttelse fra andre

- Begynnende planlegging mot nytt omsorgsnivå

Neste omsorgsnivå

vite hwor er

(Vråle \& Mjøsund, 2005)

når det gjelder tilhørighet og eventuelle opplevelser av tap, forpliktelser til viktige andre, alder, diagnose og tidligere selvmordsatferd. Klinisk skjønn, som innebærer en samlet helhetlig vurdering av de nevnte forholdene i møte med pasienten, benyttes av erfarne fagfolk. 
I tillegg til åpenbare risikofaktorer og symptomer gjør man også en helhetlig vurdering av pasientens væremåte og evne til å gjøre forpliktende avtaler. Opplevelser av at pasienten er unnvikende, gjennom blikk eller annen nonverbal kommunikasjon, kan danne grunnlag for iverksetting av $\varnothing \mathrm{kt}$ beskyttelse. Om n $\varnothing \mathrm{d}$ vendig, giøres vedtak om fotfølging. Fotfølging er ikke direkte beskrevet i norsk lovverk. De fleste avdelinger har interne kvalitetsbeskrivelser av beslutningsprosessen og ansvarsforhold for oppfølging av selvmordsnære pasienter. Det er ansvarlig lege som, ofte på et tverrfaglig observasjonsgrunnlag, beslutter både iverksetting og oppheving av fotfølging og vite hvor er. Fotfølging kan også iverksettes som akutttiltak av annet personale dersom det anses nødvendig. Tiltaket skal da snarest mulig bringes inn til ny vurdering av ansvarlig lege. Alle vedtak og endringer av tiltak for å beskytte pasienter mot selvmord stiller store krav til en effektiv og hensiktsmessig dokumentasjon og informasjonsflyt. Dette omfatter både regelmessig dokumentasjon i journal og at beskyttelsestiltak rapporteres ved alle vaktskifter.

Pasientens rett til informasjon og brukermedvirkning kan ivaretas ved at pasienten informeres nøye om vurderinger og beslutninger, og ved at han blir tatt med på råd ved vurdering av selvmordsfare og behov for tilsyn. Det kan selvsagt oppstå interessemotsetninger, som at pasienten ikke $\varnothing$ nsker fotf $\varnothing$ lging mens personalet vurderer det som nødvendig. Det blir da viktig å vise at man har oppfattet uenigheten, og at man inviterer til samarbeid og medbestemmelse innenfor de rammer som fotfølging medfører.

\section{Introduksjonsfasen}

Når fotfølging er besluttet, iverksettes den straks. Parallelt med dette må man dokumentere og informere pasienten, eventuelle pårørende og resten av personalet. Pasienten må få begrunnelse for tiltaket og informasjon om hvordan det administreres. Den som har primæransvar for pasienten, bør være mye sammen med pasienten, slik at samværet også kan omfatte relasjonsbygging. Det må være klargjort hvem som har det behandlingsmessige hovedansvaret, slik at pasienten vet hvem han kan ta opp viktige tema med. Pasienten kan få en kopi av vaktplanen så han vet hvem han til enhver tid skal være sammen med på en vakt. Pasienten må slippe å måtte forholde seg til mange personer.

Vedtaket om fotfølging skal dokumenteres i pasientens journal. Hver psykiatriske enhet må ha kvalitetsbeskrivelse av fotfølging, som må være tilgjengelig for så vel personalet som for pasienter og eventuelle pårørende.

\section{Hovedfase 2}

I denne fasen er noen sammen med pasienten i alle situasjoner og gjennom hele døgnet. I tillegg til beskyttelse mot selvskade og relasjonsbygging, omfatter denne fasen ledelse og administrasjonsarbeid.

\section{Beskyttelse}

For å beskytte pasienten mot selvmord har pasienten begrenset frihet, aksjonsradius og handlingsrom. Avhengig av pasientens lidelse og impulsivitet vil fotfølging oftest skje innenfor rammen av avdelingen, med reduserte muligheter for aktiviteter. Dette tiltaket krever oversikt og nærhet til pasienten, men fordrer samtidig diskresjon og respekt for pasientens integritet. Det å ha noen innen en armlengdes avstand til enhver tid kan være en påkjenning. For om mulig å avlaste pasienten noe for den lidelse og krenkelse som kontrollen kan påføre ham, kan man bekrefte overfor pasienten at man kan forstå noe av den belastningen det må være å ikke få være alene, og ikke selv bestemme over egne aktiviteter og eget liv. Man

kan vise til nødvendigheten av dette for å beskytte mot skade, men uttrykke vilje til å prøve å finne fram til et samvær som på tross av kontrollen og nærheten, likevel er diskret. I intimsituasjoner som når pasienten er på WC, eller dusjer, er det særlig viktig å være kreativ på å vise diskresjon og avstand innenfor de rammer fotfølging krever. Diskresjon kan ivaretas ved at man har pasienten "i фyekroken" og ikke ser rett på ham. Ved samvær i dagligstua kan man bla i en avis mens man samtidig opprettholder $\varnothing$ yekontakt. For å gjøre samværet mer meningsfullt for pasienten kan man finne fram til aktiviteter som ikke innebærer fare, som å spille et slag bordtennis eller se en videofilm.

\section{Relasjonsarbeid}

Selv om det kan være et etisk dilemma å invitere til en terapeutisk allianse med en som er i en situasjon han ikke $\varnothing$ nsker, har man erfaring for at det er viktig å bringe inn essensielle tema i samtaler med pasienter som har fotfølging (Vråle \& Mjøsund, 2005). Invitasjonen til slike samtaler bør være "timet" avventende, men samtidig tydelig og med engasjement.

Pasienten må få en invitasjon til samtaler med så vel behandler som med primærkontakt i miljøet. Slik kan han få en begynnende opplevelse av at noen vil snakke med ham om det som er så vondt og strevsomt, og at noen tåler å romme det som kommer. Det å gjøre møtet personlig, at man byr på seg selv som behandler, er også viktig. En samtidig avventende holdning kan gi pasienten den tid han trenger før han eventuelt beslutter seg til å åpne seg. En terapeutisk allianse kan skape håp om at det finnes hjelp. De ulike bidrag til den terapeutiske relasjonen kan skisseres slik:

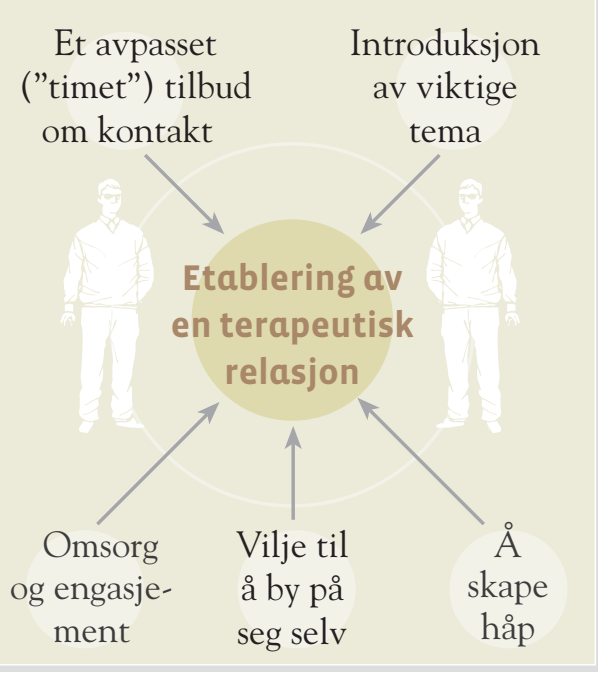

(Vråle \& Mjøsund, 2005)

Det er mange tema som kan være betydningsfulle for pasienter som er selvmordstruet. Hva som er viktig, må man lete etter i dialog med hver pasient.

\section{Noen tema for samtaler}

Pasientens livssituasjon da selvmordsproblemene oppsto, kan forklare og gi en opplevelse av sammenheng og mening for pasienten. Hvordan var pasientens relasjoner? Var det noe på arbeid eller skole som gjorde livet så strevsomt? Hvordan har pasienten greid å ivareta sine grunnleggende fysiske behov som det å sove, være i aktivitet og innta næring? Hvordan var pasientens psykiske helse? 
Er det problemer med $\varnothing$ konomi eller bolig? Er det eksistensielle spørsmål som har vært vanskelige? Dette er tema som det kan kjennes godt å snakke om, som det kan være godt at noen forstår og vet noe om, områder det kanskje kan gjøres noe med. Å gjenvinne krefter ved å få hjelp til en god natts s $\varnothing v n$ og et bedre næringsinntak har en terapeutisk effekt, og kan være omsorg og gi kraft.

Man kan samtale med pasienten om selvmordsproblemene. Er de knyttet til situasjoner eller hendelser? Hvordan arter selvmordstankene seg? Når oppstår selvmordsimpulsene? Har pasienten en selvmordsplan, og hva omfattes den av? Hvordan ser han på døden? Disse spørsmålene er viktige i vurderingen av selvmordsfare, men kan også ha en terapeutisk effekt når de deles med en bekreftende og st $\varnothing \mathrm{t}$ tende terapeut. Å dvele ved disse vanskelige tema kan kanskje gi pasienten opplevelse av at noen forstår. Det kan gi lindring, slik at han kan fatte noe mot, mening og håp igjen. I dette arbeidet må man ta i bruk både teoretiske kunnskaper om hva som kan lede til opplevelse av håpløshet og meningsløshet, og våge å virkelig føle med og leve seg inn i pasientens verden. Som terapeut kan man trolig representere håp gjennom et forutsigbart og meningsbærende nærvær. Man kan også medvirke til nytt håp og ny mening gjennom at pasienten opplever å få anledning til å samtale om essensielle tema. $\AA$ få innsikt i og dele med andre hva som gir brist i opplevelsen av mening og sammenheng, kan kanskje lindre noe av pasientens smerte. Det å dele tanker rundt disse tema kan bryte noen tabuer rundt selvmord. Ved det kan en behandlingsallianse starte. Dette krever nærhet til pasienten både fysisk og psykisk, men også en avstand og ettertanke i f.eks. samtaler og refleksjoner mellom kolleger.

\section{Overgang til neste omsorgsnivå}

Fotf $\varnothing$ lging innebærer frihetsber $\varnothing$ velse og bør derfor avsluttes så raskt som mulig, men heller ikke for tidlig. Vurdering av behovet for å opprettholde fotfølging bør skje fortløpende og i et samarbeid både med pasient og i det tverrfaglige teamet. Man kan snakke med pasienten om hvordan han vurderer selvmordsrisikoen og hvordan det vil være å være litt på egen hånd. Noen vil hevde at pasienten da, om han virkelig er selvmordstruet, vil holde tilbake informasjon og se en mulig- het til å ta sitt liv om han får være litt for seg selv. Det kan imidlertid også være et signal til pasienten om at han er medansvarlig og blir regnet med, slik at hans selvfølelse og tilh ørighet styrkes. Den terapeutiske alliansen vil også vurderes som viktig når man skal oppheve fotfølging (Vråle \& Mjøsund, 2005). Det er behandlingsansvarlig lege som har ansvar for på et tverrfaglig vurderingsgrunnlag å oppheve fotfølging. Vite hvor er er spesielt krevende når det gjelder fortløpende vurdering av selvmordsrisiko, pasientens forpliktelse til liv, allianse med behandlere og hvor lenge pasienten kan være på egen hånd eller hvor ofte han må ha tilsyn. 5 eller 15 minutter er en konkret tidsramme for hvor ofte pasienten skal ha tilsyn, men rytmen i hvor ofte pasienten trenger å ha tilsyn, må vurderes fortløpende av den som har ansvar for å "vite hvor pasienten er". Selv om dette tiltaket er beskrevet $\mathrm{i}$ avdelingens kvalitetshåndbok, vil gjennomføringen være avhengig av behandlernes kompetanse både når det gjelder vurderinger av selvmordsrisiko og evne til relasjonsbygging.

\section{Administrasjon}

Oppdaterte prosedyrer vedrørende oppfølging av selvmordsnære pasienter må være integrert i sengeposten og hos de ansatte. I forhold til den enkelte pasient må det vurderes hvem som skal ha primæransvaret for å følge opp pasienten. Det bør legges til rette for at den som har primæransvaret, også får anledning til å være mye sammen med pasienten. Dette gir en god mulighet for et begynnende terapeutisk arbeid som kan gjøre at tiden med fotfølging kan bli mer meningsfull og kanskje kan kortes ned. Fortløpende observasjoner og vurderinger skal dokumenteres og formidles til personalet, pasienten og de pårørende.

\section{Avsluttende kommentarer}

I oppfølging av pasienter med høy selvmordsrisiko står vi overfor en del utfordringer. Det å behandle en pasient som er alvorlig selvmordstruet, må utf $\varnothing$ res av kompetent helsepersonell. Med kompetent menes både terapeutisk relasjonskompetanse, klinisk kompetanse innenfor psykiatri og psykisk helsearbeid, bevissthet om sentrale verdier og kunnskap om lovverket. Når en person er alvorlig selvmordstruet, skal han både ha nødvendig førstehjelp og etter hvert mer langvarig behandling.

Konsekvensene av feil i vurdering av selvmordsfare kan bli store. Selvmordsrisikovurdering og beskyttelsestiltak er derfor viktige fagutviklingsområder. Den relasjonsbyggende funksjon ved oppfølging av selvmordsnære pasienter er avgjørende for pasientens opplevelse av å få hjelp. Ivaretakelse av selvmordsnære pasienter er viktig og utfordrende. Det er en oppgave som fordrer kvalifisert helsepersonell, i likhet med oppfølging av pasienter med andre livstruende sykdommer. Faglige og tverrfaglige refleksjoner i evalueringsm $\varnothing$ ter og faglig veiledning, samt refleksjoner sammen med pasienter som har erfart ulike beskyttelsestiltak ved selvmordsfare, kan bidra til fagutvikling på dette området.

Utarbeidelsen av nasjonale begreper og kriterier som er underveis og som beskriver oppfølgingen av selvmordstruede pasienter i psykisk helsevern, er etterlengtet.

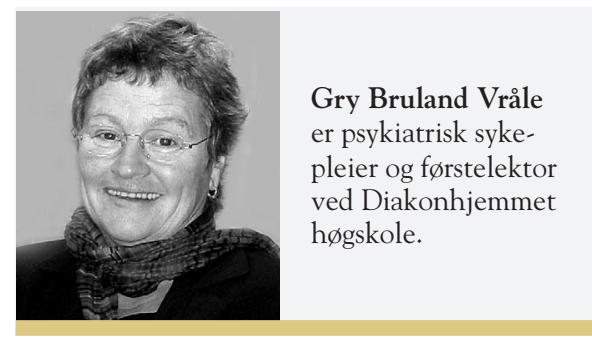

\section{Referanser}

Bowers, L., Gournay, K., \& Duffy, D. (2000) Suicide and self-harm in inpatient psychiatric units: a national survey of observation policies. Journal of Advanced Nursing 32, 2, 437-444.

Cleary, M., Jordan, R., Horsfall, J., Mazoudier, P., \& Delaney, J. (1999). Suicidal patients and special observation. Journal of Psychiatric Mental Health Nursing 6(6), 461-467.

Dodds, P., \& Bowels, N. (2001). Dismantling formal observation and refocusing nursing activity in acute inpatient psychiatry: a case study. Journal of Psychiatric Mental Health Nursing 8, 183 -188.

Vatne M. (2001) Selvmordsproblemer og psykiatrisk sykepleie - argumenter for skriftlig kontrakt som et terapeutisk verkt $\phi y$. Vård i Norden 21, 32-37.

Vråle, G. B., Finne, G., Zahl, J., \& Ystad, E. (2000). Is i magen. Tidsskriftet Sykepleien 88, 17, 58-61.

Vråle, G. B., \& Mjøsund, N. (2005). Terapeutisk fotf $\phi$ lging. Tidsskriftet Sykepleien 5, 68-71.

Vråle, G. B., \& Steen, E. (2005). The dynamics between structure and flexibility in constant observation of psychiatric inpatients with suicidal ideation. Journal of Psychiatric and Mental Health Nursing 12, $513-518$. 